\title{
Popis a konstrukce astrolábu podle raně středověkých textů ${ }^{i}$
}

\section{Marek Otisk}

\section{I.}

V posledních desetiletích 10. století se v latinské křest’anské Evropě objevily první konstrukční texty o astrolábu. Nejprve vznikly v Katalánsku a záhy se rozšiŕily po lotrinských, francouzských a německých školách. Spolu s návodem na stavbu astrolábu se od prvotního uvedení literatury o tomto astronomickém př́stroji psaly také traktáty pojednávající o jeho užívání. Předlohou dvou rozličných typů latinských textů o astrolábu byl první nám dnes známý překlad či volný výklad arabského pojednání, jehož vznik se klade do okruhu Lupita (Llobeta, Senofreda) z Barcelony. ${ }^{\text {ii }} \mathrm{Z}$ pera katalánského autora se dochoval soubor textů označovaný jako tzv. Sententiae astrolabii, ${ }^{\text {iii }}$ patrně pouze část konstrukčního pojednání o stavbě astrolábu De mensura astrolapsus ${ }^{\text {iv }}$ a zřejmě také předmluva k oběma textům začínající slovy Ad intimas summe philosophie.

V křest’anské Evropě záhy začala vznikat další přepracování a doplnění této skupiny textů. Sententiae astrolabii získala novou podobu

Studie vznikla v rámci grantového projektu GAČR č. 401/08/0053.

Mimo jiné adresát listu Gerberta $\mathrm{z}$ Remeše, v němž je žádán o vlastní překlady astronomických textů, o nichž se předpokládá, že to byly překlady spisů o astrolábu. Viz Gerbertus 1966, Epistola 24, s. 47 ,Itaque librum de astrologia translatum a te michi petenti dirige, ... " Srov. např. Poulle 1995, s. 227-237; Lattin 1932, s. 58-64; Millàs Villacrosa 1931, s. 195; a mnoho dalších.

iii Millàs Villacrosa 1931, s. 275-293.

iv Millàs Villacrosa 1931, s. 293-295. Srov. např. Bergmann 1985, s. 116-147.

v Millàs Villacrosa 1931, s. 271-275; resp. Gerbertus 1899, s. 370-375. 
v díle De utilitatibus astrolabii, jehož autorství bývá někdy připisováno Gerbertovi z Remeše, ale pravděpodobněji vznikl v okruhu Gerbertových přátel nebo žáků, př́padně ve skupině kolem Gerbertova studenta a adresáta řady dopisů pojednávajících o specializovaných tématech quadrivia, Konstantina z Fleury, opata v Micy. ${ }^{\mathrm{i}}$

Bud' ještě na severovýchodě Pyrenejského poloostrova nebo pravděpodobněji ve školách na území dnešní Francie či Německa vznikla modifikovaná podoba textu o stavbě astrolábu, tzv. De mensura astrolabii neznámého autora. ${ }^{i i}$ Větší množství nepřesností $v$ tomto kratičkém pojednání byly patrně prríčinou dalších pokusů o sepsání konstrukčních návodů ke stavbě astrolábu. Kromě obtížně identifikovatelného fragmentu Libellus de astrolabio iii je Ascelinem z Augsburgu sepsán v prvních letech po roce 1000 spis Compositio astrolabii. iv Před polovinou 11. století následně vzniká nejrozšířenější kodex o měření času a dalších úkonech na astrolábu v raném středověku a to včetně jeho stavby, jehož sestavovatelem byl Heřman z Reichenau. Vedle drobně upravené varianty spisu $D e$ utilitatibus astrolabii do ní zařadil vlastní přepracování konstrukčních pokynů, jemuž dal osvědčený název De mensura astrolabii. ${ }^{\mathrm{v}}$ Takto vzniklo v latinské křest’anské Evropě na konci 10. a v první polovině 11. století

Gerbertus 1899, s. 109-147. Hlavní důvody editora díla N. Bubnova k připsání autorství Gerbertovi viz Gerbertus 1899, s. 109-110. Další diskusi nabízí nap̌r. napřr. Zuccato 2005, s. 194; Burnett 1998, s. 330-334; Borst 1989, s. 46-58; Bergmann 1985, s. 148-174; D. C. Lindberg 1978, s. 60-61; van de Vyver 1931, s. 266-290; a mnoho dalších. Gerbertovy dopisy Konstantinovi viz Gerbertus 1899, s. 6-8, 23-35.

ii Millàs Villacrosa 1931, s. 296-302. Blíže viz např̀. Bergmann 1980, s. 75-88; odlišně pak Burnett 1998, s. 338-339.

iii $\quad P L 90$, c. 955D-960A. Na zařazení tohoto díla viz např. Bergmann 1985, s. 96-99.

iv Burnett 1998, s. 345-351.

v Drecker 1931, s. 203-212. 
hned několik verzí naučných rad o stavbě astrolábu, kdežto jediné dochované ${ }^{i}$ pojednání o užití astrolábu.

Tato studie se proto zaměří na popis (především podle druhé kapitoly spisu De utilitatibus astrolabii) a návod ke stavbě astrolábu zejména podle děl Compositio astrolabii Ascelina z Augsburgu a De mensura astrolabii Heřmana z Reichenau. Cílem této studie je tedy nejen představit raně středověké konstrukční návody na výrobu nejrozšířenějšího středověkého astronomického př́stroje, ale také vysvětlit umístění jednotlivých konstrukčních prvků na astrolábu jakožto modelového zobrazení nebeské sféry. V neposlední řadě by měly být objasněny odlišnosti raně středověkého astrolábu od pozdějších středověkých podob této pomůcky.

\section{II.}

Za původce astrolábu byl povětšinou označován Ptolemaios, ${ }^{\text {ii }}$ který trojrozměrnou sféru promítl do plochy (plana sphaera) a arabský původ latinského středověkého astrolábu prozrazuje už obvyklý název př́stroje,

i Pomineme-li A. Borstem editovaný fragment, který zřejmě vedle Lupitových (?) překladů nebo výkladů bezprostředně vychází také z De utilitatibus astrolabii - na text viz Borst 1989, s. 120-127.

ii Ptolemaiův spis Planisphaerium uvádí do geometrických základů stereografického zobrazení sférických kružnic v ploše, ale v Almagestu Ptolemaios užíá termín astroláb k označení armilární sféry. Za původce astrolábu může být označen také Eudoxos z Knidu (4. stol. přn.l.), který je spojován s konstrukcí rete astrolábu, nebo Apollónios z Pergé (3. stol. př.n.l.), př́íp. Hipparchos z Níkaie (2. stol. př.n.l.). Z pozdní antiky se pak o podobu astrolábu, která se již velmi přibližuje středověkému př́ístroji zasloužili napřr. Theón z Alexandrie (4. stol. n.l.) a jeho dcera Hypatiá z Alexandrie (4./5. stol. n.l) či její žák Synesios z Kyrény (4./5. stol. n.l). V křest’anském prostředí se astroláb objevuje v okruhu východních učencủ, jakými byli Jan Filoponos (6. stol. n.l.) a Severus Sebokt (7. stol. n.l.). Blíže viz např. Neugebauer 1949, s. 240-256. 
jehož jméno v různých podobách variuje kolem tvaru walzachora: Wazzalcora, Walzagora, waltalchora apod. ${ }^{i}$ Astroláb představuje dvojrozměrný model trojrozměrné světové sféry a k zobrazení prostorových poměrů v ploše slouží stereografická projekce, jejíž výhodou je, že umožňuje kruhy světové sféry zobrazovat v plošné podobě jako kružnice nebo př́mky. Pomineme-li méně rozšířený sférický astroláb, byla nejčastěji světová sféra na desce astrolábu zobrazována projekcí z jižního pólu. ${ }^{\text {ii }}$

Astroláb se skládá z několika složek, přičemž hlavní část tvoří základní kruhová deska (tradičně nazývaná matka, mater), na níž jsou nejprve pomocí stereografické projekce zaneseny tři kruhy světové sféry (rovník a oba obratníky) a, jak uvádí autor díla De uitilitatibus astrolabii, dva kolury, tj. obdoba poledníků, které procházejí oběma póly sféry a protínají rovník v tzv. jarním a podzimním bodu, tedy v době, kdy je Slunce ve znamení Berana a Vah, tzn. když dochází k jarní a podzimní rovnodennosti (kolur rovnodennosti), resp. v bodech zimního a letního slunovratu, tj. v době, kdy je Slunce ve znamení Raka a Kozoroha. iii Při projekci sféry z jižního pólu představuje samotný střed astrolábu severní

Gerbertus 1899, s. 374: „Est autem Wazzalcora divina mente comparata, quod latine sonat plana spera, quae etiam alio nomine astrolapsus Ptolemaie. In qua Wazzalcora secundum coeli rotunditatem formata naturali ratione tota coelestis sphaerae describitur forma et omnia ritu coelestium figurationum architectonica ratione notatur, quam paulo post describam." Gerbertus 1899, s. 114-115: „...hanc Walzagoram, id est planam sphaeram Ptolomaei seu astrolapsum, ...“; Drecker 1931, s. 206-207: „In metienda igitur subtilissimae inventionis Ptolomaei waltalchora, id est, plana sphaera, quam astrolabium vocitamus,..."

ii Podrobněji viz např. Křišt'an 2001, s. 56-57; Bergmann 1985, s. 38-41.; ad.

iii Gerbertus 1899, s. 117-118: „Est quidem Walzagora tabula ad coeli rotunditatem conformata, cujus utraque superficies aequali spatiorum interstitio quadrifidis ab ipso centro per diametrum fusis lineationibus partita est, id est coluris, qui a septentrionali vertice in diversa deducti quaternas in partes zodiacum dividunt ita, ut unus per Arietem et Libram, alter per Cancrum et Capricornum permeet." 
pól světové sféry (bod A). Tímto bodem prochází dvě přímky, které odpovídají kolurům. První se táhne zprava doleva a znázorn̆uje kolur rovnodennosti: Doprava vede tzv. východní linie, tedy úsečka $A B$, nebot' zde vycházejí hvězdy a Slunce; doleva pak tzv. západní linie, tj. úsečka AC, nebot' zde hvězdy i Slunce zapadají. ${ }^{i}$ Kolur slunovratu protíná první kolur v pravém úhlu a rovněž prochází bodem $\mathrm{A}$. V horní části se nachází tzv. poledníková linie, nebot' Slunce se zde nachází nejvýš nad obzorem, $\mathrm{k}$ čemuž dochází v poledne, čímž vzniká úsečka $\mathrm{AD}$, ve spodní části pak směr od jihu k severu vyznačuje úsečka AE. ${ }^{\text {ii }}$

Ascelin i Heřman ve svých návodech ke konstrukci astrolábu doporučují začít zakreslením středního kruhu, tj. rovníku. Jeho velikost je libovolná a má pouze zohledňovat velikost celého př́stroje. ${ }^{\text {iii }}$ Střed této kružnice (bod A) odpovídá severnímu pólu a procházejí jím oba zmíněné kolury (Heřman rovněž používá arabského označení alcot ${ }^{\mathrm{iv}}$ ) a body, $\mathrm{v}$ nichž přímky kolurů protínají rovník (tj. body rovnodenností a slunovratů), člení rovník na čtyři stejné čtvrtiny. Tyto body zároveň

Gerbertus 1899, s. 118: „Ipsum autem centrum harum trajectum secatione linearum a littera designatur. Quarum linearum sinistram $\boldsymbol{b}$ adnotatam Almarech, id est, orientalem ab ortu siderum et diei, dexteram autem, ubi est c Almagrip, id est, occidentalem ab occasu siderum et diei, appellant."

ii Gerbertus 1899, s. 118: „Superiorem autem, cui d ascribitur, Walzazene, id est, lineam meridianam, eo quod sol, ipsa ascendendo attacta, sex dimensis horis, meridiem efficiat et descendendo ad occasum vergere incipiat. Inferiorem autem, ubi est $\boldsymbol{e}$, Cathezeuuel, id est lineam aequalitatis vel mediatricem sphaerae. Et est illa, quae a Meridie ad Septentrionem protenditur, quam radius solis vel umbra gnomonis solstitialis in tropico aestivo designat.“

iii Burnett 1998, s. 346: „Componas circulum equinoctialem ad arbitrium.“ Drecker 1931, s. 204: „... tres primum circulos invenire debemus. Quorum medium, qui aequinoctialis coelestis circuli vice nomen obtinet, juxta quantitatem tabulae, ne maximum dumtaxat praepediat, ad libitum moderari convenit.“

iv Podobně také $P L 90$, c. 955D. 
označují čtyři světové strany: B vymezuje východ; C západ; D sever a E jih. ${ }^{\mathrm{i}}$

Spis De utilitatibus astrolabii vymezuje kruhy světové sféry pomocí zodiaku a ekliptiky (uvádí rovněž, že pojmenování ekliptiky souvisí se zatměním, k němuž dochází při souběhu drah Slunce a Měsíce). Rovník, tj. kruh rovnodennosti, pojmenovaný podle stejné délky dní a nocí při rovnodennostech, rozděluje zvířetníkový kruh na dvě stejné poloviny a prochází znameními Berana a Vah. ${ }^{i i}$ Naproti tomu letní a zimní obratník stanoví meze roční okružní dráze Slunce, včetně planet, jejichž dráhy pohybu jsou spoluurčovány ekliptikou. Obratník Raka se jeví jako menší a je blíže středu astrolábu, tedy uvnitř rovníku, zatímco obratník Kozoroha je vně rovníku. ${ }^{\text {iii }}$

K přesnému zanesení těchto obratníků na astroláb uvádí Ascelinus i Heřman podrobný návod. Nejprve je nutno rovník rozdělený na kvadranty

Drecker 1931, s. 204: „Quem centro A diligenter circumscriptum in quatuor aequa partiaris punctis B. C. D. E., et sit B a sinistris orientale punctum, $C$ huic oppositum a dextris occidentale, $D$ inferius septentrionale, $E$ superius meridianum. Dehinc, apposita regula, per B.A.C. puncta, rectam lineam a fine ad finem tabulae deducito, id est, ab oriente in occidentem. Itemque per D.A.E., id est, a septentrione in meridiem alteram lineam. Quas videlicet lineas quadrifariam dividentes arabes alcot nominant; nos culuros."

ii Gerbertus 1899, s. 118: „In cujus antica planitie trifidi zodiaci inscribuntur circuli, quorum unus aequinoctiali ratione medio collocatum cursus Arietis et Librae sine deviatione notat. Qui etiam aequinoctialis dicitur, eo quod ibi pari compensatione lucis noctisque spatia dimetiantur. Dicitur et eclipticus: nam, dum inibi sol lunaque pariter coeunt, quilibet eorum necesse est ut eclipsim patiatur.“

iii Gerbertus 1899, s. 118-119: „Ex duobus autem terminalibus unum cernis interiorem circulum in confinio centri circumactum, qui, naturali observata ratione, quantum centro est vicinior, tantum circumactione contractior, qui circulus Canceri tropicus aestivus dicitur. In extremis tabulae oris dilatiori circulatione circulus Capricorni, id est, tropicus hiemalis inscribitur. Quorum inscriptiones, ad instar coelestis sphaerae collocatae, signiferi latitudinem circuli includunt et solis ceterorumque planetarum cursibus limitem ponunt." Srov. Pseudo-Beda, Libellus de astrolabio, c. 955D. 
(tj. $90^{\circ}$ ) rozčlenit v každé čtvrtině na tři stejné díly, tedy vytvořit dvanáct částí po $30^{\circ} .^{\mathrm{i}} \mathrm{V}$ rámci této jedné dvanáctiny kruhu je pak nutno vyčlenit třicet úseků $\left(\mathrm{tj} .1^{\circ}\right)$ a odpočítat jich 24 od východní úsečky AB. ${ }^{\mathrm{ii}}$ Heřman je $\mathrm{v}$ tomto bodě podrobnější a dodává pokyny k nalezení dělení dvanáctiny kruhu na 30 částí: Stačí rozdělit uvedený úsek kružnice na pět oddílů (každý bude zahrnovat vzdálenost $6^{\circ}$ ) a odpočítat čtyři z nich (tj. $24^{\circ}$ ) -

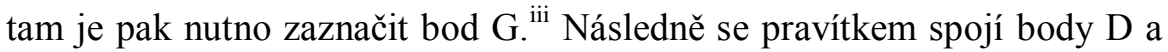
G. V místě, kde prrímka vedoucí body $\mathrm{D}$ a $\mathrm{G}$ protne východní část koluru rovnodennosti, se vynese další bod $(\mathrm{H})$ a nakonec se vede kružnice se středem v A a poloměrem v bodě $H .{ }^{\text {iv }}$ Takto vznikne vnější kruh, tj. zimní obratník, nebot' vzdálenost $24^{\circ}$ od rovníku (bod G) přibližně odpovídá deklinaci Slunce, tj. úhlová vzdálenost od rovníku, při slunovratu (bod D). Podobně (pouze v kvadrantu BAE) se vynesou body F a posléze I, jakožto průsečík úsečky DF a koluru rovnodennosti, čímž bude vyznačen poloměr (AI) kružnice obratníku Raka. ${ }^{v}$ Opětovně je to proto, že umístění bodu F

Burnett 1998, s. 346: „Hunc divide in partes quatuor, e quibus unam ad te versam partire per tria intersticia quorum unumquodque continet tiginta gradus ut omnibus simul collectis compleantur nonaginta, quem unaquęlibet portio quadrifidę sperę necessario si recte sit partita debet includere." Podobně také Drecker 1931, s. 204.

ii Burnett 1998, s. 346: „Quo fao, ut circulos terminales ratione possis invenire, sume viciniores orientaci linee gradus triginta et ex his viginti quatuor circumscribe, horum ultimum cauta observatione denota."

iii Drecker 1931, s. 204: „Sed ut hoc facilius fiat, quadrantes singulos in tria divide, ut scilicet unaquaeque tertia XXX partes capiat, et duas tertias $C$ contiguas in $V$ singulas partire, unamquamque quinarum partem VI de XC partibus subintelligens claudere. Ex his quinque partibus, IIII utrinque circa C secerne et punctis ... G inscribe."

iv Burnett 1998, s. 346: „Dum hoc feceris, accipe regulam et impone eam note impresse, ita coaptando ut ex altera sui parte septemtrionalis linee supersideat extremitati. Regula vero ita posita quocunque in loco orientalis linee tangat eminentiam affige notam, quam usque dum attingere possit distrahe pedes circino, et dum attigerit eam circumvolve et habebis hiemalis solstitii circulum." Podobně Drecker 1931, s. 205.

Drecker 1931, s. 205: „Item in puncta ... D et $F$ regulam ponens, et ubi lineam praedictam B.A.C. tangit, notam I infigens, nihilominus fixo in A et I circino, 


\section{AIOHIP II. 3}

zhruba odpovídá opačné maximální deklinaci Slunce. Celý postup zaznačení kolurů a tři paralelních kruhů světové sféry dokládá obr. 1 .

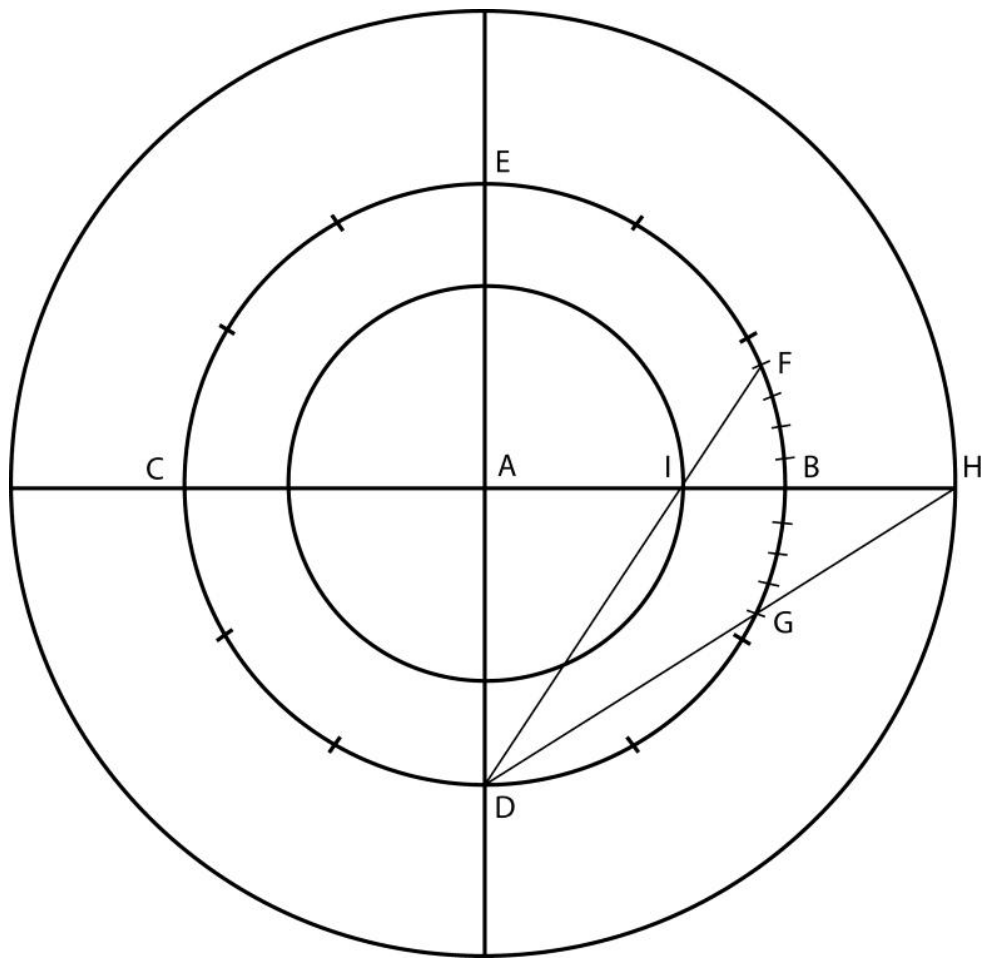

Obr. 1 - Vynesení rovníku, obratníků a kolurů na přední stranu astrolábu.

Vynesením těchto kružnic a přímek vzniká na astrolábu základní souřadnicový systém. Vše je vztaženo k severnímu pólu světové sféry (střed astrolábu, bod A) a pomocí kolurových př́mek je vymezen horizont (kolur rovnodennosti, úsečka $\mathrm{CB}$ ) i zenit a nadir (kolur slunovratu, resp.

minimum aestivi solstitii circulum centro A circinato. " Podobně Burnett 1998, s. 346-347. Srov. také PL 90, c. 955D-956D. 
body E a D) pozorovatele na rovníku. Jenže pozorovací místo uživatele, pro nějž jsou psány rané křest’anské latinské texty o astrolábu, se nenachází na rovníku, proto bylo zapotřebí vynést na astroláb i skutečný horizont místa, v němž se astroláb užívá.

V raném středověku se rozlišovalo podle antické tradice sedm základních klimat, která byla určena mimo jiné zeměpisnou šířkou. Právě zeměpisná šířka vymezuje horizont pozorovacího místa a pojednání o klimatech se stalo běžnou součástí konstrukčních či uživatelských návodů k astrolábu. Spis De utilitatibus astrolabii je v tomto směru nejpodrobnější, nebot' uvádí dvě samostatné a relativně rozsáhlé kapitoly o umístění klimat podle zeměpisní šířky, zjišt’ování přítomnosti v konkrétním klimatu i výčet lokalit v daném klimatu. ${ }^{i}$ Heřman vyjmenovává všech sedm klimat a poté uvádí návod na vynesení horizontu, označován také jako tzv. první almukantarát (viz níže), pro klima, v němž se nachází Reichenau, kde působil, tj. sedmé klima. ${ }^{\text {ii }}$ Text Libellus de astrolabio je konstruován pro

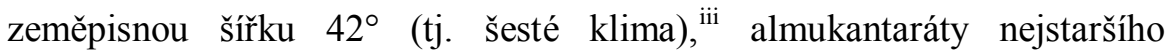
dochovaného latinského astrolábu z Andalusie zhruba odpovídají zeměpisné šířce Barcelony (tj. 41 ${ }^{\circ} 30^{\prime}$ ), ${ }^{\text {iv }}$ Ascelinus uvádí hodnotu prvního klimatu, ale nabízí i možnost vynesení almukantarátů podle jiných zeměpisných šířek. ${ }^{\mathrm{v}}$

i Gerbertus 1899, s. 138-146.

ii Drecker 1931, s. 205: „His circulis ita inventis, quodcunque clyma construere velis, ejus clymatis altitudinis quot sint gradus vide, utpote primi climatis XV, secundi XXIII, tertii XXX, quarti XXXVI, quinti XLI, sexti XLV, septimi XLVIII, ... verbi gratia, si nostrum, id est septimum, clyma volueris metiri,..."

iii PL 90, c. 956D-957A: „Accipiebant circulum a $b c d$, qui divisus est in CCCLX gradus, et ex parte b a abstrahebant latitudinem ipsius climatis cujus astrolabium quaerebant construere, ut de clima 6, in qua est supina Roma, Germania, abstrahebant XLII, cujus terminus est $g$, et de g ducebant lineam per $h$ usque i, d c hinc ducebant lineam de c per l."“

iv Viz např. Samsó, 1995, s. 239-252.

v Burnett 1998, s. 347: „Primi climatis latitudo .xvi. gradibus terminatur. ... His factis, ducenda est regula ab orientali linea usque ad determinationem 
Dalším nezbytným krokem při konstrukci astrolábů je proto vynesení tzv. almukantarátů, tj. s obzorem rovnoběžných kružnic, které procházejí stejnou výškou nad horizontem. Tyto kružnice se na desce astrolábu zanášejí v horní polovině a jejich počet by měl kvůli přehlednosti korespondovat s velikostí celého prŕístroje. Pomocí almukantarátů je možno např. určovat úhlovou výšku Slunce nad horizontem, nebot' mezi prvním almukantarátem a zenitem je vždy $90^{\circ}$. ${ }^{i}$

Ascelin i Heřman popisují složitý proces správného vyznačení almukantarátů. Nejprve je nutno na rovníku vyznačit zeměpisnou šiřku místa, pro nějž jsou almukantaráty vyneseny (bod L). Tento bod je nalezen odpočtem patřičných stupňů na rovníku, když se počítá od východu dolů (tj. v kvadrantu BAD). Dále je nezbytné vyznačit bod K, který odpovídá téže zeměpisné šířce, tentokrát $v$ kvadrantu CAE, opětovně počítáno od koluru rovnodennosti, avšak nyní nahoru (směrem k bodu E). ${ }^{\text {ii }}$ Takto vzniká na rovníku polokruh $\left(180^{\circ}\right)$, který je vymezen body K a L. Tento polokruh musí být rozdělen na 36 částí. Ascelin navrhuje dělení na třetiny $(180 / 3=60)$, každou $\mathrm{z}$ třetin pak opětovně na třetiny, čímž vznikne 9 částí ( 60 / 3 = 20), poté každou devítinu na půl, takže bude 18 částí (20 / 2 =10) a nakonec každou osmnáctinu znovu na půl. Vznikne tak 36 částí, kde každá bude zahrnovat vzdálenost $5^{\circ}(10 / 2=5)$.ii Heřman je nyní

latitudinis climatis, sive sit hęc latitudo .xvi. ut pote primi climatis, sive quilibet alius numerus occurrat, prout climatum diversitas extat."

Gerbertus 1899, s. 119: „In superiori autem medietatis regione hemicycli et integri etiam orbiculi artificiosa industria machinati sunt, quos dicunt Almucantarat, id est progressionarios solis, qui frequenti circuitione et crebra retorsione, alii extractiores, alii contractiores, certa et necessaria locatione coronantur, in quibus magna hujus instrumenti consistit efficacia. In quorum intervallis gradus ascensus et descensus solis diurni et menstrui geminato in utrisque partibus XC permetiuntur. Sunt ergo in hac Walzagora quindecim orbiculi, quibus singulis sesquipertitis XC completur numerus, id est quadrans totius circuli.“

ii Burnett 1998, s. 347. Podobně také Drecker 1931, s. 205.

iii Burnett 1998, s. 347: „Spacium quoque quod inter has duas extremitates extractę latitudinis relinquitur primo tribus intervallis distinguitur, sekundo 
stručnější a navrhuje dělení na šestiny (180 / 6 = 30) a každou šestinu znovu na šest dílů, čímž vznikne potřebných 36 úseků, každý s výměrou $5^{\circ}$ (30 / $6=5)$. Pokud bychom těchto pětistupňových dílků poskládali 72 , vznikl by celý kruh $\left(360^{\circ}\right){ }^{\mathrm{i}}$

Poté má být vedena polopřímka, která začíná v bodě $\mathrm{C}$ a prochází bodem K; někde daleko nad horní částí astrolábu se protne s prrímkou koluru slunovratu; na tomto místě bude vyznačen bod M. Ze stejného bodu $\mathrm{C}$ jsou pak vedeny další polopřímky, které protínají rovník v místech, kde bylo vyznačeno všech sedmatřicet značek šestatřiceti dílků polokruhu, a pokaždé se vyznačí jejich průnik s kolurem slunovratu. Poslední polopř́mka prochází bodem L a její průnik se svislým kolurem na astrolábu vymezí bod $\mathrm{N}$. ${ }^{\text {ii }}$

Dalším úkolem je nalezení středu mezi body $\mathrm{M}$ a $\mathrm{N}$ na prímce koluru slunovratů. Do tohoto středu se umístí kružítko, s jehož pomocí

unumquodlibet trium interstitiorum in tria, tercio unumquodque secunde divisionis spacium in duo, quarto tercię dimensionis bipertita membra iterum in duo diminuentur. Hac divisionis sic habita ratione, puncta repperientur .xxxvii., et intervalla .xxxvi. quo in unam quantitatem numeri coadunata, sub singulis acceptis .v. reddunt summam nonaginta." Patrně omylem je uvedeno, že souhrn všech vyznačených částí dává dohromady $90^{\circ}$, místo správných $180^{\circ}$.

i Drecker 1931, s. 205: „Postea emiciclum a K per E et B usque ad L in VI partire et unamquamque sextam in VI itidem punctis impressis partire, et hoc facto habetis a K usque ad L intervalla XXXVI, singula quinas partes de CCCLX totius circuli partibus complectentia."

ii Drecker 1931, s. 205-206: „Deinde regulam in C et K puncta ponens, vide, quo in loco tangat lineam meridianam per D.A.E. longe extra circulos in alia tabula, super quam wahtalchora metienda ponitur, prolongatam, ibique $M$ notam scribe, sicque, non mota hinc, id est de C puncto regula, ad singula per ordinem, quae a $K$ ad L feceras puncta, eamdem regulam ponito, et ad singulas positiones praefatam D.A.E. lineam, ubi a regula tangatur annotato, donec tricies et sexies ipsa linea notata in $C$ et L puncta regulam ponas et ubi saepe dictam tangat lineam, trigesimum septimum signum, id est $N$ facias. “ Srv. Burnett 1998, s. 347. 
bude obkroužena kružnice, která bude procházet body $\mathrm{M}, \mathrm{N}$ a východním $\mathrm{i}$ západním bodem (body $\mathrm{B}$ a $\mathrm{C}$ na koluru rovnodennosti), čímž vznikne první almukantarát, tj. horizont pozorovacího místa. ${ }^{\mathrm{i}}$ Následně se hledá střed mezi druhými značkami (ty, které jsou nejblíže $\mathrm{M}$, resp. $\mathrm{N}$, směrem ke středu mezi M a N) na vertikální linii DAE a kružnice (na astrolábu se vynese jen část této kružnice) procházející druhým a předposledním bodem (názorněji viz obr. 2). Takto vznikne druhý almukantarát a stejným způsobem je postupně na astroláb vyneseno podle Ascelinova a Heřmanova návodu osmnáct těchto kruhů, které budou od sebe vzdáleny $5^{\circ}$.i Dreckerem editovaná verze textu De mensura astrolabii končí tuto pasáž zmíněním, že takto jsou narýsovány almukantaráty pro zeměpisnou šiřku $48^{\circ}$.iii Jiné dochované varianty spisu De mensura astrolabii uvádí ještě návod pro nalezení prvního almukantarátu pro další časová pásma. iv

Burnett 1998, s. 347: „His ita punctorum rationi adęquatis notationibus, perquiratur medietas inter longissime a se distantes notas. Hoc in loco medietatis positus circinus, ut utrasque notas extremas attigere valeat, circumducatr, et fiet primum ALMUKANTARAT." Viz také Drecker 1931, s. 206.

ii Drecker 1931, s. 206: „Iterum spatium lineae, quod inter proximum signum ab $M$ et proximum ab $N$ complectitur, in duo dividens et, centrum in medio figens, alterum itidem emiciclum curvabis. Eodem modo spatii inter lineae tertium ab M et tertium ab $N$ signum inventa medietate, tertium emiciclum debes incurvare; sicque ordinatim per singula ejusdem lineae signa interius utrinque progrediens, spatiumque, quod inter ipsa continetur, in duo dividens, nunc semiplenos, nunc integros circulos circinabis, donec ad medium signorum perveniens, octodecim orbiculorum almucantarat consumabis, sicque ab $N$, id est a primo almucantarat usque ad medii orbiculi centrum XC gradus computantur, per singula scilicet ampilogrammorum intervalla quinis gradibus enumeratis." Srov. Burnett 1998, s. 347-348.

iii Drecker 1931, s. 206.

iv Viz např. $P L$ 143, c. 383D-384A. Migneho vydání přetiskuje edici B. Peze. 


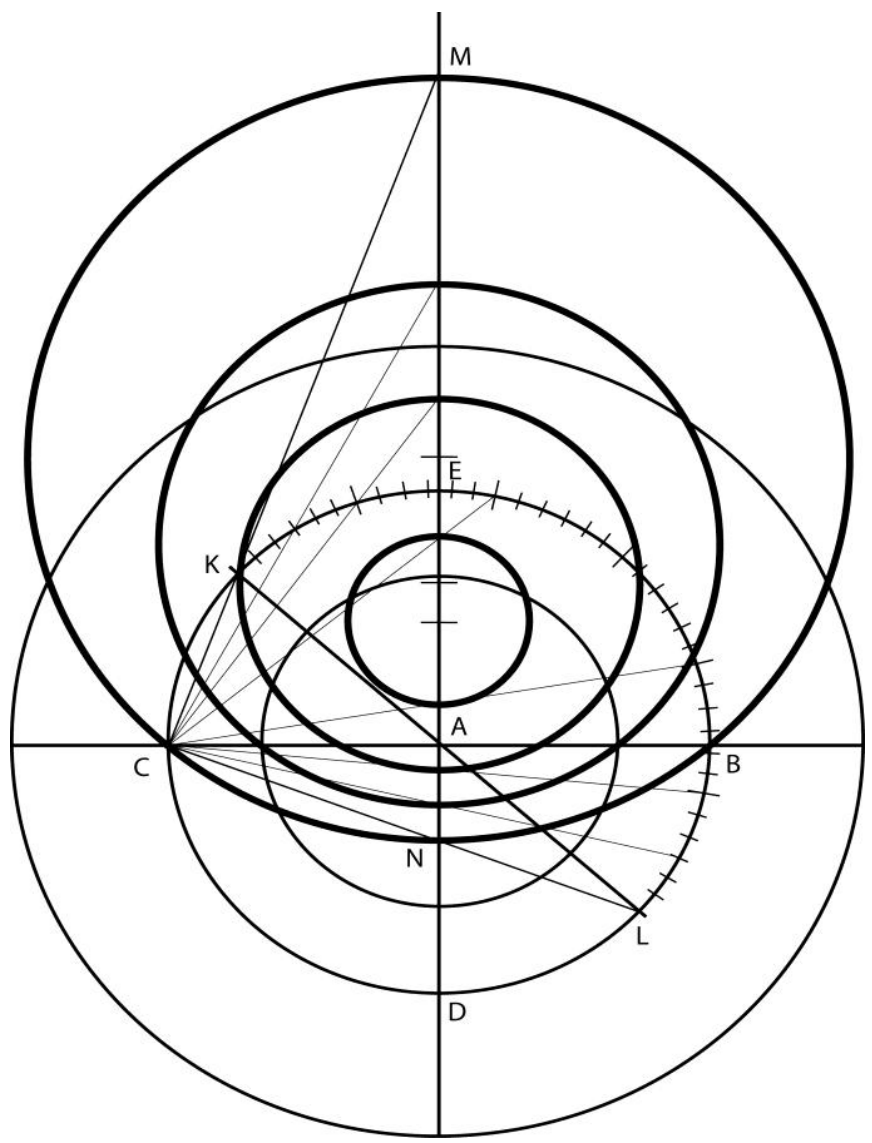

Obr. 2 - Vyznačení pruního almukantarátu pozorovacího místa (horizontu) a almukantarátů pro výšku $15^{\circ}, 30^{\circ}$ a $60^{\circ}$ nad horizontem podle Heřmana z Reichenau.

Ve spodní části desky astrolábu jsou zaznačeny křivky nerovnoměrných hodin, tj. ve středověku obvyklý způsob označování délky hodiny podle východu a západu Slunce - vždy je mezi východem a 
západem Slunce 12 hodin, jejichž délka se v průběhu roku mění, proto se nazývají nerovnoměrnými hodinami. Prostor pod prvním almukantarátem je rozdělen na dvanáct částí, když u horizontu jsou výseky menší, kdežto u obratníku Kozoroha širší. Napravo jsou zaznačeny dopolední hodiny, nalevo odpolední. De utilitatibus astrolabii uvádí z arabštiny převzaté názvy jednotlivých nerovnoměrných hodin. ${ }^{\mathrm{i}}$ Čáry těchto hodin neodpovídají kružnicím, nýbrž se (s výjimkou polední př́mky) jedná o křivky, jejichž tvar se kružnicím velmi blíží. Proto je jejich přesné vyznačení na desce astrolábu složitým úkolem, který byl v průběhu středověku řešen různě. ${ }^{\text {ii }}$

Odlišné návody pro jejich narýsování nabízí také oba rané latinské konstrukční texty o astrolábu. Počátek je však stejný: části obratníkových kruhů, které zůstaly pod prvním almukantarátem, je nutno rozdělit na 12

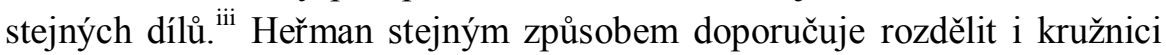

Gerbertus 1899, s. 119: „Inter quos extremos orbes in plaga septentrionali artificiosa rationis positione Hototalzagag, id est breves lineae horarum, aequa intervallorum partitione instruuntur ita, ut interiori angustia extracta decurrendo latitudine exterius amplius pateant. Quorum media est linea diagonalis Meridiei, cujus ex utrisque partibus simul cum ipsa, geminatis senis, duodecim horarum meta constituitur, et impressis nominibus singulae denotantur. Et haec sunt illarum nomina Arabica, quae subtus vides formulae inscripta:

XII Ethesiafer

I. Elewiul

XI. Aldimata

II. Athenia

$X$. Alhansira

III. Atheziza

IX. Ethezea

IV. Arrabea

VIII. Ethemima

V. Alcamiza

VII. Escebea

VI. Escendelisza

Quarum dextera lineatio antemetidianas, sinistra autem postmeridianas horas cauta discretione insignat et diligenter adhibito horoscopo demonstrat."

ii Detailně viz např. Křrišt’an 2001, s. 380-390.

iii Burnett 1998, s. 348: „Ita compositis almukantarat, spaium quod retro almukantarat vacuum remanent in duodecim per circulos qui dicuntur terminales dividatur, medio indivisio manente." 
rovníku, ${ }^{\mathrm{i}}$ čímž dosáhne přesnějšího, ale složitějšího vyznačení čar nerovnoměrných hodin než Ascelin. Ascelinus totiž dále ř́́ká, že je nezbytné nalézt kružnici, která protne oba první body na obratníkových kružnicích a když se pomocí kružítka tímto zpơsobem zaznačí část kružnice mezi oběma obratníky, vznikne čára první hodiny. ${ }^{i i}$ Mnich z Reichenau navrhuje metodou pokusu a omylu nalézt kružnici, která protne značky na všech třech kružnicích, které nebyly zahrnuty prvním almukantarátem (viz obr. 3). ${ }^{\text {iii }}$

i Drecker 1931, s. 206-207: „Hoc modo perfectis almucantarah ampilogrammis spatium trium primitus dictorum circulorum, quod infra primum almucantarat ex parte scilicet $D$, id est septentrionali, remanet, XII horarum locationi aequaliter distribui hoc modo: Initio ab ipso almucantarath a parte $C$ sumpto, spatium cujusque trium circulorum usque ad lineam D.A.E. sex antemeridianis horis aequaliter dispertire. Similiter ab ipsa D.A.E. linea usque ad almucantarath ex parte B sena in singulis circulis metiens intervalla postmeridianis horis deputabis. "

ii Burnett 1998, s. 348: „Postea circino apposito tam diu moderare ut secunda puncta intimi et extimi circuli altero pede circini tangantur, et tunc facias lineam ab extremo circulo usque ad intimum, qui pes dicitur horarum, et habebis primę horę certum terminum, et hoc sit communiter datum de cęteris discriminationibus horarum.“

iii Drecker 1931, s. 207: „Postea circini accepti unum pedem tali in loco figere debes, ut alter tria puncta primae horae limitem in singulis scilicet circulis signantia possit attingere, et ita circinando finalem primae horae lineam inter ipsos tres circulos curvabis. Eodemque modo per singulas horas faciens nunc contrahendo, nunc dilatando in diversis locis circinum, prout punctorum positio poscit, figendo, singularum horarum finales lineas circinabis; sicque singulis horis nascentur intervalia ad interiorem quidem circulum contractiora, ad exteriorem vero latiora, quae videlicet ipsa septentrionalis D.A.E. in medio limitat linea." 


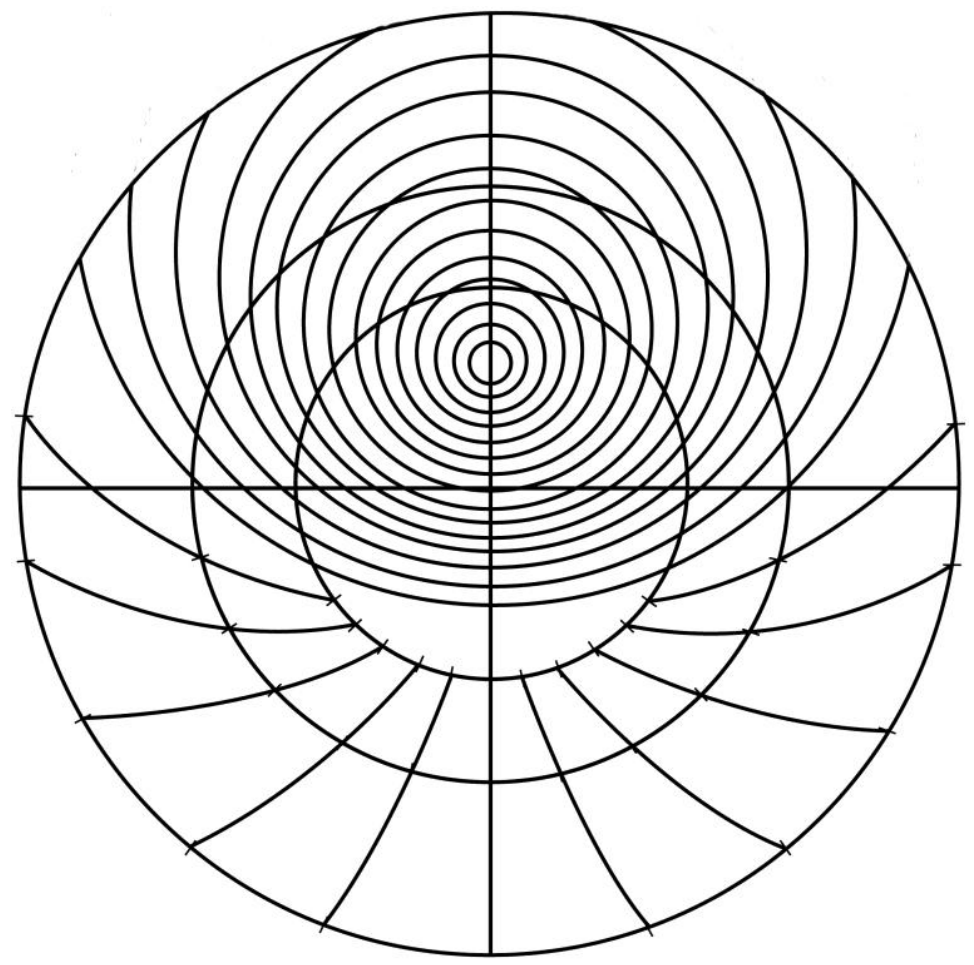

Obr. 3 - Vyznačení čar nerovnoměrných hodin podle spisu De mensura astrolabii Heřmana z Reichenau.

Zatímco paralelní kruhy obratníků a rovníku i oba kolury (přímky) jsou při projekci z jižní polokoule zaznačeny pro všechny zeměpisné šiřky totožně, almukantaráty i čáry nerovnoměrných hodin jsou závislé na konkrétním umístění pozorovatele. Právě proto Heřman opětovně uvádí, že jeho návod k zhotovení astrolábu je určen pro sedmé klima, tedy cca $48^{\circ}$ 
zeměpisné šiřky. ${ }^{i}$ Již raně středověké latinské astroláby umožňovaly své použití na různých místech pomocí vyměnitelných kotoučů, na nichž byly vyneseny almukantaráty a čáry hodin pro různá klimata. ${ }^{\text {ii }}$ Pro snadnější manipulaci s celým př́strojem se tyto vyměnitelné tabule vkládaly do hlavní desky astrolábu (mater) a nahoře se ponechávala aktuálně užívaná tabule pro místo pozorovatele.

Tloušt'ka všech vyměnitelných tabulí měla být shodná s rozměry vyvýšeného okraje celého prŕstroje, který se tradičně označoval jako limbus, autor De utilitatibus astrolabii používá $\mathrm{z}$ arabštiny převzatého označení alnogiza. Na vertikální linii byl vyroben výřez k zachycení nehybného postavení aktuálního kotouče $\mathrm{e}^{\mathrm{iii}}$ a nechybí ani závěsný kroužek pro snadné držení přístroje při měření úhlových vzdáleností v horní části astrolábu. ${ }^{\text {iv }}$ Vystupující lem základní desky astrolábu byl opatřen stupnicí pro odpočet stupňů a určování rovnoměrných hodin, tj. hodin, jakých užíváme dnes, tzn. každý den (bez ohledu na aktuální východ a zápas Slunce) má stejných 24 hodin. ${ }^{\mathrm{v}}$

Prvotní latinské popisy a konstrukční návody na stavbu astrolábu se u právě představených základních prrímek a kružnic na přední straně přístroje liší od později ve středověku běžně užívaných astrolábů

Drecker 1931, s. 207: „Talibus ita mensuris et perigraphiis quaternas VII scilicet clymatum tabellas insignito."

ii Gerbertus 1899, s. 121: „Eisdem etiam perigraphiis caeterae exarantur tabulae, quorumlibet sint climatum, quamvis paulisper pro locorum et climatum mutatione ipsi Almucantarat varientur. De qua varietate certa ratio dabitur in suo loco."

iii Gerbertus 1899, s. 121: „Cujus in extremis labris coronata gyratione prominens umbo tenaci soliditate affigitur, quem dicunt Alnogiza, qui in altum porrectus eminentes aliorum climatum tabulas in se suscipiendo concludit. Ad quas concipiendas frons ejus parvo terebratur foramine, cui acuta tabularum infiguntur capitula: Quod foramen meridianae respondet regulae. Cujus crassitudo non altius extollitur, quam tabularum capacitas postulat.“

iv Gerbertus 1899, s. 120.

v Gerbertus 1899, s. 120. 
v některých podstatnějších detailech. Pomineme-li zmíněné potíže s narýsováním výsečí pro nerovnoměrné hodiny, jsou nejviditelnějšími odlišnostmi absence azimutů, jakýchsi poledníků kolmých na almukantaráty, a tzv. soumrakové čáry, která odpovídá almukantarátu $18^{\circ}$ pod obzorem. ${ }^{\text {i }}$

\section{III.}

Pohyblivou část přední strany astrolábu tvoří tzv. rete, tj. sít', raně latinské texty užívají rovněž označení volvellum, př́ípadně $\mathrm{z}$ arabštiny převzaté pojmenování alhancabut, resp. alhancaput apod. ${ }^{\text {ii }}$ Tato sít' umožňuje manuálně nastavovat aktuální polohu zodiaku a vybraných hvězd, které jsou na rete vyznačeny, a takto najít aktuálně odpovídající postavení hvězd na obloze $\mathrm{v}$ danou dobu na daném místě. Zásluhou této pohyblivé sítě lze mimo jiné poznávat noční hodiny podle východu hvězd, určovat aktuální polohu pozorovatele apod. ${ }^{\text {iii }}$

Rete se skládá z několika kruhů. Vnitřní kruh tvoří zodiak, na němž jsou vyznačena všechna zvířetníková souhvězdí. Tento kruh je vůči obratníkům i rovníku umístěn excentricky a je rozdělen kolurem rovnodennosti na dvě části, takže prvních šest znamení zodiaku (od Berana

i Viz např. Křišt’an 2001, s. 150-153.

ii Drecker 1931, s. 207: „Deinde volvellum seu rete, quod arabes alhancaput nominant, crebra percussione foratum, hoc modo erit metiendum. "Srov. Burnett 1998, s. 348.

iii Gerbertus 1899, s. 121: „Quibus tabulis supersidet Alhancabut, id est versatile volvellum, quod manuali versatione ad demonstrandam coelestis sphaerae volubilitatem et ad demonstrationem horarum volvitur. Nam ejus versationibus et gradibus solis eisque respondentibus horoscopis per partes signiferi circuli certis locis designatis, lucidissime horarum proprietates patefiunt et correptiones et crescentiae noctium et dierum probantur. Est enim illud excavata machinatione insculptum secundum interstitia praedictorum circulorum et positionem stellarum fixarum, per quas horae noctis dignoscuntur.“ 
k Vahám) zabírá menší část obvodu kružnice (tato znamení jsou staženější), kdežto druhý sextet zviŕretníkových znamení pokrývá větší část obvodu zodiakální kružnice a tyto díly ekliptiky jsou zaznačeny jako širší. ${ }^{i}$ Na zodiakálním kruhu jsou rovněž vyznačeny stupněii a na vrcholu (tj. na počátku Kozoroha) je umístěn ukazatel, tzv. almeri. Tento ukazatel slouží k určování hodin, postavení hvězd, nastavování zodiaku podle rovníkových souřadnic atd. ${ }^{\text {iii }}$

Velikost sítě by měla odpovídat zimnímu obratníku na vyměnitelných tabulích přední strany astrolábu. Poté je opětovně v souladu s dřive vytvořeným vyznačen rovník, který je rozdělen na 72 částí (tzn. na díly po $\left.5^{\circ}\right) .{ }^{\text {iv }}$ Chybět nesmí ani obratník Raka a oba kolury, které rozdělí celou sít' na čtyři stejné díly. Následně je vyznačen zodiakální kruh, k čemuž se využije severojižní kolur. Je nutno nalézt bod Q, který je středem úsečky OP, když bod O se nachází na místě, kde se obratník Raka

i Gerbertus 1899, s. 121: „Sunt certe in ipso tres circuli, quorum interior in duos hemicyclos per diametrum partitus est, quibus lineali divisione secatis senis signis, duodecim signorum numerus redditur. ... Est etiam ita naturaliter depositum, ut in septentrionali parte sublimetur, in meridiana autem ad confinia inferiorum demergatur."

ii Gerbertus 1899, s. 122.

iii Gerbertus 1899, s. 122: „In quo etiam acuti machinati sunt denticuli, qui certis in locis collocati stellas adnotant fixas, per quas noctis cognoscimus horas, quae propriis etiam nominibus Arabicis inscripti sunt. In cujus rotunditatis fronte exstans est denticulus super Capricornum positus et ad ipsum umbonem porrectus, qui calculando summam numeri,in epiphania umbonis positi naturales discriminat horas. Qui dicitur Almeri, id est calculator, et illud desuper positum tabula involutionem contegit.“

iv Burnett 1998, s. 348: „Ambitus eius amplitudinem metire secundum tropici hiemalis quantitatem; semicirculi in eodem positi revolutionem interiorem equinoctialis circuli coęqua dimensioni; eiusdem quoque latitudini .xxiiii. maiora intervalla in umbone computata tribue." V textu je zjevně chyba nebo vynechávka - rozdělení na 24 částí mohlo být pouze základem pro další dělení každé čtyřiadvacetiny na třetiny, čímž by vzniklo potřebné číslo 72, příp. došlo jen k záměně čísel 72 a 24 . Heřman navrhuje toto dělení provést na okraji celého prŕístroje a vyjmenovává i účel vyznačené stupnice - Drecker 1931, s. 210. 
dotýká koluru slunovratu v horní části astrolábu, a bod $\mathrm{P}$ vyznačuje styk obratníku Kozoroha s týmž kolurem v jeho spodní části. Kolem bodu Q je následně opsána kružnice, která obsáhne celý letní obratník a celá bude vepsána do zimního obratníku. ${ }^{\text {i }}$

Zodiak je nezbytné rozdělit na dvanáct částí a to pomocí bodu Q a třetin kvadrantu na rovníku. S využitím pravítka se postupně vyznačí průsečíky zodiakálního kruhu s úsečkami mezi stupni světové sféry (rovníku, obratníků) a pólem ekliptiky (bod Q). Zodiak proto nebude rozdělen rovnoměrně, nýbrž ve spodní části budou vyneseny větší distance, v horní menší (viz obr. 4). ${ }^{\text {ii }}$ Do jednotlivých částí zodiakálního kruhu se vepíśi všechna znamení - mezi rovníkem a obratníkem Raka to jsou Beran, Býk a Blíženci; od letního obratníku nazpět k rovníku Rak, Lev a Panna; od rovníku směrem k zimnímu obratníku Váhy, Štír a Střelec; a poslední

Drecker 1931, s. 207: „Descriptis primo in tabula ejus aliquantum spissiora, tribus circulis ejusdem, cujus et supra quantitatis aequinoctiali videlicet, hiemali atque aestivo solstitialibus, eodemque modo cum lineis rectis, quas coluros dixi, in quatuor aequa, ut supra, divisis, colurum unum versus meridiem a septentrione directum a puncto ubi aestivum minimum secat usque ad punctum, ubi ex opposito jungitur maximo hiemali circulo, in duo divide et centro in medio fixo zodiacum circulum, in quo tota hujus artis consistit efficacitas, ita circumscribe, ut minimum totum infra se continens circulum ex una ei conjungatur, ex opposita per diametrum parte maximo adunetur, mediumque circulum altrinsecus simul et alium colurum ad singula puncta intersecet, atque per ipsius coluri lineam in bina emisphaeria, sed non aequaliter dividatur;..." Srov. Burnett 1998, s. 348.

Drecker 1931, s. 207-208: ,Maximum tertium circulorum in XII partire, unumquemque scilicet quadrantem in tria. Dehinc regulam rectam ad singulas XII partes et ad trium circulorum centrum ponito, et zodiacum, quem feceras circulum, ubi ad singulas positiones a regula tangitur, lineis secato, et ita XII in eo spatia sed non aequalia efficiens in minoris emisphaerii senis spatiis sena signa ab ariete usque libram contra mundum a dextra scilicet in sinistram ordinato. In majoris quoque totidem spatiis alia a libra usque ad arietem signa." Srov. Burnett 1998, s. 348. 
část od obratníku Kozoroha k rovníku tvoří Kozoroh, Vodnář a Ryby. ${ }^{\mathrm{i}} \mathrm{Na}$ vrcholu zodiaku (tj. na rozhraní znamení Střelce a Kozoroha) je umístěn ukazatel (calculator, almeri). ${ }^{\text {ii }}$ Stejným způsobem jako u vyznačení vzdáleností jednotlivých znamení se posléze zaznačí jejich stupně, tedy v jižní části budou stupně zodiakálního kruhu zabírat méně prostoru než v severní části. Heřman doporučuje rozdělit každé znamení na šest dílů po pěti stupních. ${ }^{\text {iii }}$

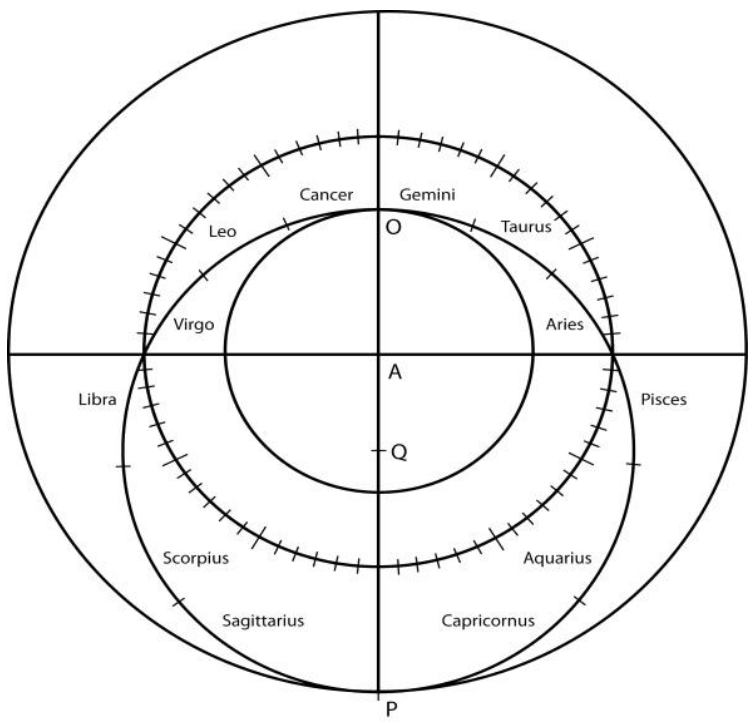

Obr. 4 - Př́prava rete astrolábu a zaznačení dvanácti částí zodiaku.

i Drecker 1931, s. 208: „Sicque ab aequinoctiali circulo ad aestivum aries, taurus, gemini pertendunt; indeque rursum ad aequinoctialem cancer cum leone et virgine reclinantur. Porro idem ad hiemalem libra, scorpius sagittariusque devergunt; et inde itidem ad aequinoctialem capricornus cum aquario et piscibus resurgunt."

ii Burnett 1998, s. 348: „Quando autem huius volvelli divisio instituatur, vide ut ALMERI circumpositio umboni in eo loco ubi capita tabularum infiguntur semper sit opositum." Srov. Drecker 1931, s. 208.

iii Drecker 1931, s. 208. 
Pro další postup je užitečné zmínit, že sít' v konečné podobě obsahuje čtyři základní části: obratník Kozoroha (vnější kruh), rovník (prostřední kruh), zodiak (vnitřní kruh) a malý kruh u pólu svétové sféry. Toto rozdělení na čtyři části je důležité pro poslední krok při zhotovování rete, jímž je vyznačení vybraných hvězd podle souřadnicové tabulky. Postavení hvězd je v traktátech o astrolábech charakterizováno pomocí dvou hodnot: tzv. šiřka či délka (latitudo), která vyjadřuje umístění hvězdy $\mathrm{v}$ zodiaku, tzn. pozici v rámci poledníkových souřadnic, a tzv. výška (altitudo), která stanoví postavení na daném poledníku, tzn. stanoví místo hvězdy na rovnoběžných souřadnicích. ${ }^{\mathrm{i}}$

Zanesení stálic je názorně popsáno Ascelinem i Heřmanem. Konstruktér rete vyznačí v tabulce uvedené umístění hvězdy na určitém stupni zodiaku, položí pravítko na severní pól (tj. střed astrolábu, bod A) a př́slušným stupněm vede úsečku $A R$ až $\mathrm{k}$ okraji celého př́istroje, tedy k vyvýšenému limbu, na němž jsou vyneseny stupně, kde vyznačí bod $\mathrm{R}$. Takto získá délku hvězdy latitudo. ${ }^{\text {ii }}$ Poté od bodu $\mathrm{R}$ vyznačí na obvodové stupnici astrolábu (limbus) počet stupňů výšky hvězdy (altitudo) a to na obě strany limbu, čímž vytvoří body $\mathrm{S}$ a T. Mezi těmito body vede úsečku a zaznačí bod U, který vznikne na průniku úseček AR a ST. ${ }^{\text {iii }}$ Tento bod U je hledanou pozicí dané stálice na světové sféře při zobrazení na síti astrolábu (viz obr. 5).

Na tabulky hvězd viz např. Burnett 1998, s. 350; Drecker 1931, s. 209.

ii Drecker 1931, s. 208: „Quamcunque ergo stellam in eo locare volueris, prius in pagina subscripta contra quem gradum cujuscunque XII signorum eadem poni debeat praevide; et in eumdem gradum atque in trium circulorum centrum regulam ponens, mediam ejusdem denticuli seu stellae lineam dirige." Srov. také Burnett 1998, s. 348-349.

iii Drecker 1931, s. 208: „Postquam ab eo gradu, quo maximus a regula circulus tangitur, tot gradus in eodem maximo circulo, qui in CCCLX divisus est, iterum numera quot eidem stellae in eadem ascriptos videris pagina, et ubi numerus ipse utrinque finitur, ibi altrinsecus regulam pone, atque ubi stellae linea a regula tangitur, ibi acumen porrectionis ejus abscidatur:..." Srov. také Burnett 1998, s. 349. 
Důvod je poměrně jednoduchý: Délka (latitudo) hvězdy je vyznačena daným poledníkem (úsečka $A R$ ) světové sféry, na němž se hvězda nachází; výška (altitudo), tj. umístění na daném poledníku, je nalezena v bodě průsečíku téhož poledníku s rovinou, jejíž umístění je dáno úhlovou vzdáleností v rovníkových souřadnicích (body ST). V uvedeném př́kladě je rovina symbolizaná úsečkou ST a vyznačuje lokaci $36^{\circ}$ na devadesátistupňové výseči poledníku (AR).

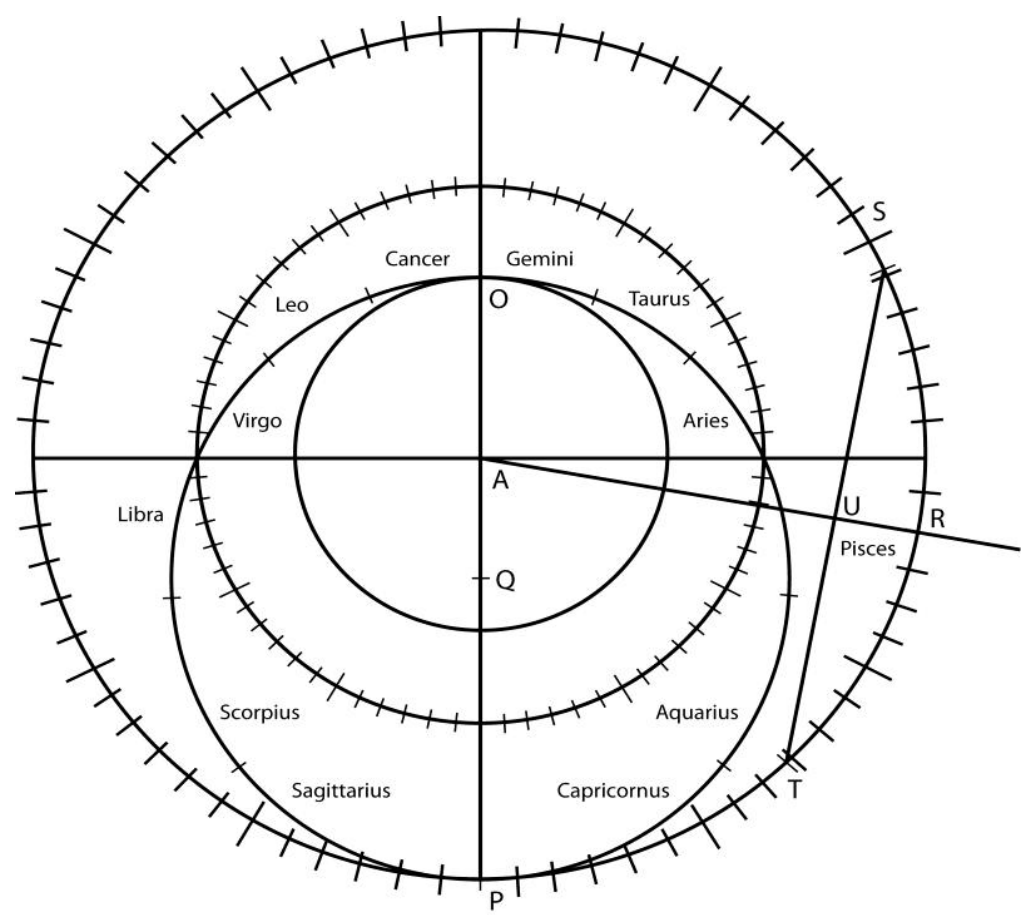

Obr. 5 - Nalezení umístění hvězdy Denebcaitoz (ı Cet) podle návodu a souřadnic Heřmana z Reichenau. 
Heřman následně umíst’uje na jednotlivé kruhy rete astrolábu šestadvacet hvězd: 1. na zodiakální kruh Alramech, Elfeca, Alhauui (Alhamum), Altahir, Delfoi a Alferah (Alferaz); 2. na kruh ve středu astrolábu Benenath, Wega, Alrif, Algol, Alhaich, Egregeh (Egregez) a Aruguba (Alrugaba); 3. na rovníkový kruh Aldebaran, Algeuhe (Algenze), Algomeisa, Aldiraan a Calbalazeda (Calhadizeda); 4. na kruh zimního obratníku Denebilgedi (Debalgedi), Denebcaitoz, Patancaitos, Rigel, Alhabor, Algurab, Alcimech a Calbalagrab. ${ }^{\text {i }}$

V Ascelinově traktátu je na kruhy rete umístěno 27 hvězd, ${ }^{\text {ii }}$ což odpovídá výčtu týchž stálic v tabulkách obou konstrukčních pojednání. $\mathrm{Na}$ síti Heřmanova De mensura astrolabii chybí pouze hvězda Alhadip, kterou Ascelin umístil k polárnímu kruhu. ${ }^{\text {iii }}$ Spis De utilitatibus astrolabii uvádí ve výčtu 29 hvězd, avšak čtyři stálice zmiňuje dvakrát. ${ }^{\text {iv }}$ Detailnější

i Drecker 1931, s. 208-209: ,Eodem modo juxta numeros in ipsa pagina singulis stellis ascriptos post alramech in ipso zodiaco Elfeca, Alhamum, Altahir, Delfoi, et Alferaz locentur. In parvulo ducto Benenath, Wega, Alrif, Algol, Altaich, Egregez et Alrugaba ordinantur. In parte vero aequinoctiali circuli a regione Tauri usque ad Virginis regionem ad hoc nihilominus relicta Aldebaran, Algenze, Algomeisa, Aldiraan et Calhadizeda statuuntur. In maximo autem hiemali circulo qui ad hunc itidem usum ab Aquario usque ad Sagittarium in extremis volvelli terminis relinquitur, Debalgedi, Denebcaitoz, Patancaitos, Rigel, Alhabor, Algurab, Alcimech et Calbalagrab, quamvis non adeo utiles, utpote in Austro juxta horizontem dimerse ponantur, ut praefata pagina subtus asscripta docet."

ii Burnett 1998, s. 351: „In parvo circulo circa centrum: Benenaz, Wega, Alriph, Algol, Alhaico, Egregez et Alrucuba, Alhadip. In equinoctiali circulo: Aldebaran, Algoze, Aldiraan, Maleuxe, Calbalzeda. In hiemali circulo: Calbalagrab, Alchimech, Algurab, Alhabor, Rigel, Gaitoz derep, Gaitoz patan, Libdideneb. In zodiaco circulo: Alramech, Elfeca, Alhauui, Altair, Delphin, Alferaz.“

iii Důvody vysvětluje W. Bergmann 1985, s. 78-88.

iv Gerbertus 1899, s. 122. 
uvedení hvězd pak představuje kapitola 17 téhož spisu, kde jsou hvězdy prezentovány podle př́islušnosti $\mathrm{k}$ souhvězdím. ${ }^{\mathrm{i}}$

Právě tabulky hvězd na rete astrolábu prodělaly v průběhu středověku mnohé proměny, což ovlivnily astronomické tabulky, z nichž vycházely původní arabské zdroje a následné latinské překlady a rozšíření užívání astromických tabulek řecké provenience. Nejen $\mathrm{v}$ dalších stoletích středověku, ale $\mathrm{i} v$ rané fázi této éry se tradovalo hned několik typů tabulek. ${ }^{\text {ii }}$

\section{IV.}

Rovněž zadní strana astrolábu se skládá z pevné a pohyblivé části. Pevný díl tvoří základní deska, pohyblivou pak záměrné pravítko, kterému se říká alhidáda. Na pevném disku jsou postupně vypsány dny, měsíce, znamení zvíŕetníku a celý obvod je skrze další dělení rozčleněn na stupně. ${ }^{i i i}$ Alhidáda, což je otočné zařízení, které se svou délkou rovná šířce astrolábu a na svých koncích je opatřeno dvakrát proděravěnými destičkami, jejichž pomocí lze zaměřit postavení sledovaného objektu na obloze (pro Slunce je menší otvor, pro hvězdy větší), slouží k měření úhlů Slunce a hvězd,

Gerbertus 1899, s. 136-138. Obsahové odlišnosti této kapitoly mezi devatenácti- a jednadvacetikapitolovou verzí shrnuje W. Bergmann 1980, s. 221-222.

ii Podrobněji viz např. Kunitzsch 1983; Kunitzsch 2005, Bergmann 1985, s. 72105; Kunitzsch 1966; ad.

iii Gerbertus 1899, s. 122-123: „Jam vero antica descripta planitie ad posticam vertatur stylus, in qua mensium et signorum habentur notitiae. Nam in interioribus circulis cauta discretione singulis mensibus proprii subscripti sunt dies. Quibus vero mensibus signa, singulis attinentia, lineali divisione superposita sunt. In exterioribus tabulae labris partes zodiaci per quadras denotantur plagas, propriis, distanctis per quinquepartita intervalla, distributae signis, quae omnia visu potius, quam dictu deprehendi possunt." 
př́padně k dalším úkonům jako je zjištování hloubky či výšky nejrůznějších objektů. ${ }^{\text {i }}$

Zatímco pojednání Compositio astrolabii vynechává pasáž o dělení kruhů na zadní straně astrolábu, Heřman poskytuje podrobný návod k jejich narýsování i rozdělení. Nejprve je nutno rozčtvrtit největší kruh, tzn. vytvořit kvadranty jako na přední straně prŕistroje, v každé čtvrtině následně vyčlenit 18 dílů, takže obvod celého kruhu bude zahrnovat 72 částí. Každý z těchto dílů lze dále rozdělit na pět úseků, čímž se vytvoří celá stupnice zahrnující $360^{\circ}$ ii

Pod takto vymezené stupně se do dalšího kruhu vepíší souhvězdí zodiaku. K tomuto lze využít již dříve provedené dělení kvadrantu na třetiny, což vytvoří dvanáct dílů na celém kruhu. Do těchto intervalů se zanesou názvy nebo symboly všech znamení a je zřjejé, že každé zodiakální souhvězdí bude zahrnovat $30^{\circ}$ ekliptiky. ${ }^{\text {iii }}$

Gerbertus 1899, s. 123: „Habetur etiam ibi Alhidada, id est verticulum, quod nos radium dicere possumus, quod ad instar regulae extensum superponitur tabulae. Cujus in capitibus binae erectae sunt pinnae, quae ad accipiendum solis radium et stellarum fixarum seu ad geometricalium mensurarum scientiam sibi respondentia bina habent foramina. Quod tactu cum torquetur, itu et reditu altitudinem solis providis demonstrat obtutibus."

ii Drecker 1931, s. 210: „Cujus extremos circulos in quatuor itidem aequa rectis lineis per centrum ductis divisos eadem qua et praedictum umbonem mensura distinguas, ut videlicet unusquisque quadrans (primum in tria et illa) in sena, id est XVIII intervalla, totus vero circuito in LXXII divisus sit, et unumquodque horum in quinos dividatur gradus, qui simul 360 complebunt." Drecker 1931, s. 210-211: „Sub his vero proximum circulorum intervallum tribus in unoquoque quadrante signis dispertiatur eorumque vocabulis inscribatur. A linea videlicet occidentali, usque ad summam australem, cui suspendicularis incantenatur circulus contra mundum Aries, Taurus, Gemini. Abhinc usque ad orientalem Cancer, Leo et Virgo. Inde usque ad imam septentrionalem Libra, Scorpius et Sagittarius. Et dehinc ad occidentalem Capricornus, Aquarius et Pisces convertantur; et unicuique signo sexies quini, id est XXX de praedictis CCCLX totius circuli gradibus deputentur." 
Dalším krokem je vyznačení všech dní v roce. K tomuto úkolu navrhuje Heřman rozdělit obvod excentrického kruhu na 12 částí, přičemž stranou ponechá jeden díl dř́ivějšího dělení kvadrantů na 18 distancí. V každé z nově vzniklých 12 částí pak určí šestiny, takže na kruhu bude 72 úseků, které spolu s jedním vynechaným dílem dají dohromady potřebný počet 73 intervalů na obvodu celého kruhu. V každém z těchto oddílů se pak vyznačí pět částí, čímž bude na kruh vyneseno všech 365 dílků dní $v$ roce $(73 * 5=365){ }^{i}$

Nakonec této části prrípravy zadní strany astrolábu je zapotřebí zaznačit měsíce. Zapisují se nad kruh dní a pod kruh znamení. Počátek je vyznačen při jarní rovnodennosti v prvním stupni Berana, kdy březen trvá ještě dva týdny (na kruhu dní je odpočítáno 14 dílků) a poté začíná duben. Pak se podle počtu dní v jednotlivých měsících vyznačují počátky a konce dubna (30), května (31), června (30), července (31), srpna (31), záŕí (30), ř́ijna (31), listopadu (30), prosince (31), ledna (31), února (28) a rovněž zbylých 17 dní března. ${ }^{\text {ii }}$ Tento kruh dní je následně rozdělen podle slunovratů a rovnodenností na čtyři části a zbývá-li místo směrem do středu

Drecker 1931, s. 211: „Et sub item aliud diebus anni CCCLX vel potius V adhuc additis dividatur: quod hoc modo facilius facies: Ab uno circuli quadrante decimam octavam partem seclude. Et hac excepta reliquum totum circuitum in XII, et unamquamque duodecimam in senas divide partes, sicque annumerata, quam secluseras, quadrantis (parte) decimam octavam in toto circulo LXXIII reperies intervalla, quibus singulis in V partitis habes circulum per CCCLXV dies divisum."

ii Drecker 1931, s. 211: „Tunc(a) vernali aequinoctio, quod moderni primo gradu Arietis, id est XV kal. Aprilis ascribendum credunt, incipiens XIIII dies post aequinoctium, id est post lineam occidentalem, in qua arietem inchoasti, Martio mensi tribue, deinde Aprili XXX, Majo XXXI, Junio XXX, Julio XXXI, Augusto XXXI, Septembri XXX, Octobri XXXI, Novembri XXX, Decembri XXXI, Januario XXXI, Februario XXVIII et Martio usque ad praefatam aequinoctii vernalis lineam XVII deputans. “" 


\section{AlOHIP II. 3}

přístroje, lze pro snadnější orientaci v rámci jednotlivých měsíců doplnit členění na pět nebo sedm dní. ${ }^{i}$

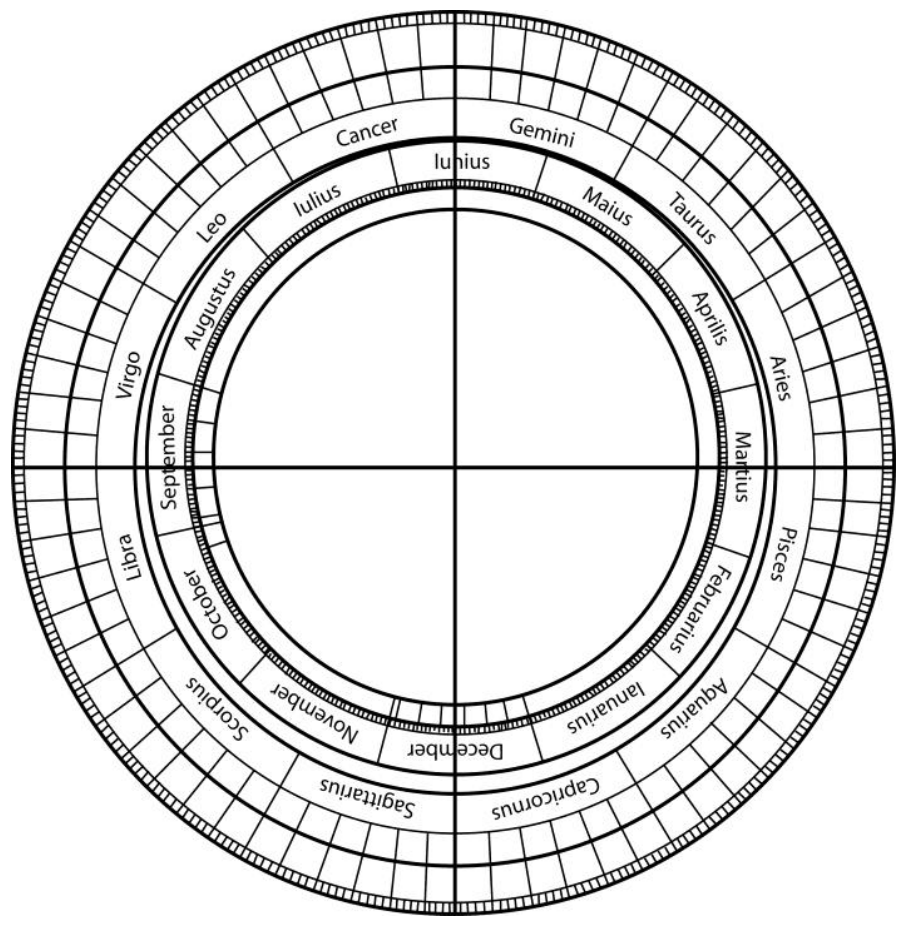

Obr. 6 - Členění zadní strany astrolábu.

Posledním prvkem při výrobě zadní strany astrolábu bylo vyznačení tzv. stínového čtverce na zadní straně astrolábu. Jeho sestrojení počíná vyměřením tří bodů, které se nacházejí uprostřed pravého horního (bod B) i spodního (bod A) a levého spodního (bod C) kvadrantu. Narýsováním úsečk $\mathrm{AB}$ a $\mathrm{AC}$ vzniká čtverec, jehož jeden úhel je v bodě $\mathrm{A}$, protilehlý ve

Drecker 1931, s. 211. 
středu astrolábu a další dva svírají úsečky $\mathrm{AB}$ a $\mathrm{AC}$ s prŕímkami dělící zadní stranu astrolábu na kvadranty. ${ }^{i}$ Mezi středem astrolábu a bodem A je vynesena diagonála, která půlí pravý spodní kvadrant. Tyto poloviny je zapotřebí rozdělit na další poloviny a poté každou z nich, tj. čtvrtiny kvadrantu, na třetiny. Tímto je prostor kvadrantu roztrríděn na dvanáct částí, a když je každá z nich rozpůlena, dosáhne se kýženého počtu 24 dílků stínového čtverce, na jehož dvě strany se tato členění vyznačí (viz obr. 7). ${ }^{\text {ii }}$ K měření pomocí tohoto čtverce se používá výše zmíněná alhidáda. iii

i Drecker 1931, s. 211-212: „Quartam ergo dierum circuli partem inter praedictas occidentalem et septentrionalem lineas in duo divide et puncto A in medio facto, aliam quoque quartam inter occidentalem et australem, et item aliam inter septentrionalem et orientalem in duo itidem dispertiens medietates punctis $B$ et $C$ notato. Tunc apposita regula in puncta $A$ et $B$ lineam rectam $a b$ occidentali linea in A dirige; item in A et $C$ regulam ponens aliam lineam a septentrionali linea item in $A$ deducito, et habes quadratum orthogonum aequi laterum, cujus unus angulus in A, alter oppositus per diagonum in centro, qui reliqui in lineis occidentali et septentrionali limitantur."

ii Burnett 1998, s. 349-350: „Ab occidentali linea spacium quod continetur usque lineam septentrionalem divide in duo. Postea singula de duobus in geminam divisionem iterum diminue. Hinc unumquodlibet horum in tria, de tribus quodlibet in bina deinde partire, hoc caute perpendens, ut inter lineam occidentalem et septentrionalem natura prodeat recti quadrati cuius quartus angelus tribus ceteris equus ut equalitas exigit recti quadrati terminetur in medio centri.“ Srov. Drecker 1931, s. 212.

iii Drecker 1931, s. 212. 


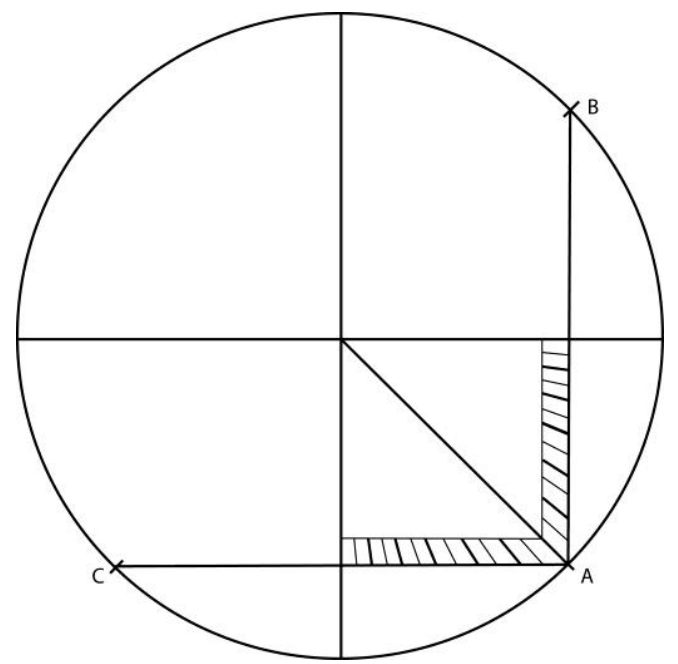

Obr. 7-Stínový čtverec na zadní straně astrolábu.

Pozdější středověké astroláby přidávaly ještě další kružnice a členění pro snadnější práci s touto pomůckou, včetně návodu pro excentrickou konstrukci kruhu s výčty jednotlivých dní, což texty z 11 . století postrádají. Krom této konstrukční rady jsou však zadní strany př́strojů velmi obdobné a na rozdíl od přední strany astrolábu není výraznějšího rozdílu mezi raně a pozdně středověkými podobami tohoto zařízení.

Celý přístroj (viz obr. 8) je držen pospolu pomocí osy zvané alchitob, která prochází základní deskou astrolábu (mater), vyměnitelnými kotouči klimat, rete a alhidádou.

Křišt’an 2001, s. 165-167. 

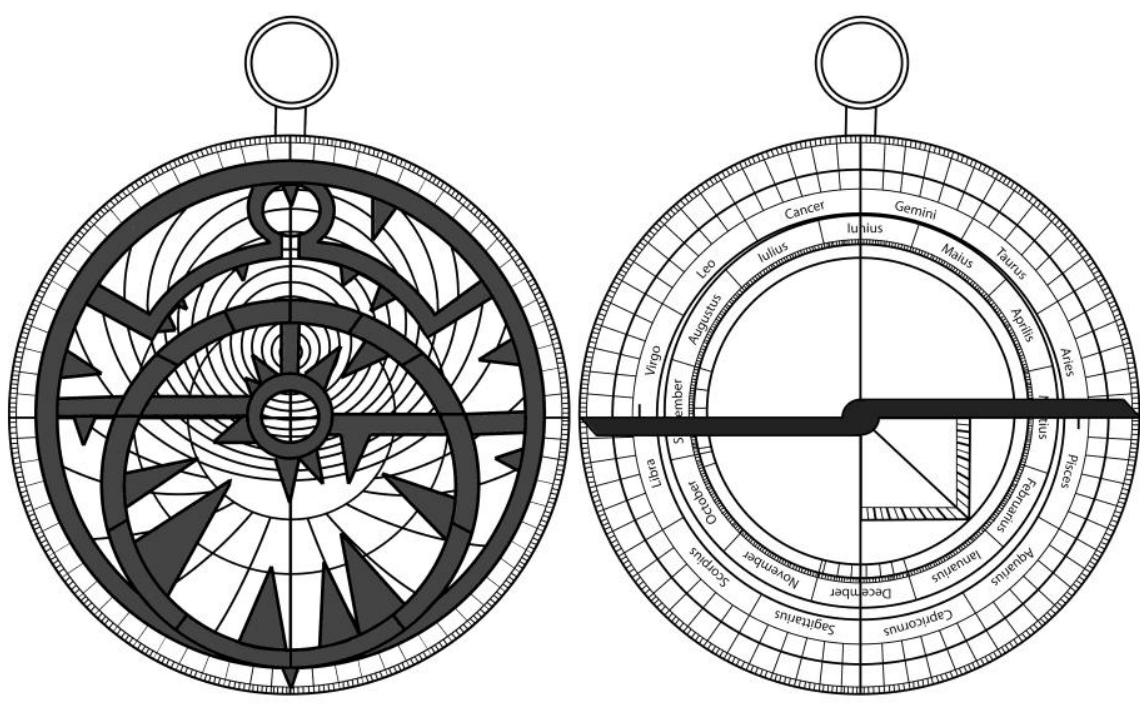

Obr. 8-Astroláb v jedné z možných konečných podob podle raně středověkých latinských textů; vlevo přední strana, včetně rete (tmavší barvou); vpravo zadní strana, včetně alhidády (tmavší barvou).

$\mathrm{Na}$ konci této osy vedoucí středem (severním pólem) astrolábu je závlačka, tzv. alferaz, která dostala své jméno podle tvaru v podobě koně (caballus). ${ }^{\mathrm{i}}$

Gerbertus 1899, s. 123: „Est etiam Alchitob, id est vectis rotundus, qui ipsi Walzagorae, in medio perforatae, ad constringendum climatum tabulas infigitur. Cui, in summo perforato, alter cuneus ex parte Alhancabut transverse inseritur, quem Alferaz, id est caballum, dicunt, eo, quod instar caballi formatus sit." 
V.

Narýsováním všech kružnic a přímek, umístěním rete i alhidády a následným spojením všech složek, včetně vyměnitelných tabulí klimat, je dokončena prríprava přístroje, který je poté možno plně používat. Když zůstanou stranou variabilní hvězdy na rete astrolábu, je zřejmé, že raně středověký astroláb konce 10. a počátku 11. století je v mnohém značně odlišný od pozdějších podob téhož přístroje. Především chybí azimuty, což je sice na první pohled jasně viditelná odchylka, ale $\mathrm{z}$ uživatelského hlediska relativně málo významná, zvláště když hlavním úkonem, k němuž se astroláb používal v prvních desetiletích své přítomnosti v latinském křest’anském světě, bylo měření času, jak jednoznačně dokládá text spisu De utilitatibus astrolabii. Ostatní odlišnosti jsou pak vesměs výhradně kosmetického rázu, když pouze usnadňují vlastní práci na přístroji (především podrobnější kružnice na zadní straně astrolábu, tzv. soumraková linie na přední straně, př́ípadně ručičkový ukazatel tamtéž, který se však neobjevuje zdaleka na všech astrolábech vrcholného nebo pozdního středověku).

Z konstrukčního hlediska lze říci, že již rokem 1000 byli křest’anští stavitelé astrolábu obstojně seznámeni s jednotlivými kroky prŕípravy př́stroje. Ascelinův traktát se liší od Heřmanova návodu jen v některých detailech. Výraznější rozdíly tkví pouze ve zjednodušené Ascelinově verzi konstrukce čar nerovnoměrných hodin, která je navíc nepřesná, nebot' dvěma body mohou být vedeny kružnice o mnoha poloměrech a $\mathrm{s}$ nepočítaně středy, ale hledání cesty $\mathrm{k}$ zanesení nerovnoměrných hodin na přední straně astrolábu byl docela závažný problém, jemuž se s různými úspěchy věnovali astronomové a matematici po celý další stř̌edověk.

Další odlišnost je rovněž v chybějícím pojednání o umístění a dělení kruhů na zadní straně astrolábu. Zde je zarážející absence zmínky o excentrickém umístění kruhu s dny v roce v Heřmanově pojednání, nebot' již i nejstarší dochovaná podoba latinského středověkého astrolábu (patrně 


\section{AIOHIP II. 3}

vzniklá kolem roku 980') zobrazuje tento kruh excentricky a patrně si také uvědomuje nezbytnost takového umístění.

Detailně o něm, včetně řady vyobrazení, viz Stevens, W. M.; Beaujouan, G.; Turner, A. J. (eds.), 1995. 


\section{Prameny a literatura:}

Bergmann, W., 1980, „Der Traktat ,de mensura astrolabii“ des Hermann von Reichenau,“ Francia. Forschungen zur westeuropäischen Geschichte 8, s. 65-103.

Bergmann, W., 1985, Innovationen im Quadrivum des 10. und 11. Jahrhunderts. Studien zur Einführung von Astrolab und Abakus im Lateinischen Mittelalter, Stuttgart.

Borst, A., 1989, Astrolab und Klosterreform an der Jahrtausendwende. Heidelberg.

Burnett, Ch., 1998, „King Ptolemy and Alchandreus the Philosopher: The Earliest Texts on the Astrolabe and the Arabic Astrology at Fleury, Micy and Chartres, “ Annals of Science 55, s. 329-368.

Drecker, J., 1931, „Hermannus Contractus - Über das Astrolab,“ Isis 16/2, s. 200-219.

Gerbertus Auriliacensis, 1899, Gerberti postea Silvestri II papae Opera Mathematica (972-1003). Berlin.

Gerbertus Auriliacensis, 1966, Die Briefsammlung Gerberts von Remis. Weimar.

Hermannus Contractus, PL 143, De mensura astrolabii, Migne, J.-P. (ed.), c. 379-390.

Křišt’an z Prachatic, 2001, Stavba a užití astrolábu. 


\section{AIOHIP II. 3}

Kunitzsch, P., 1966, Typen von Sternverzeichnissen in astronomischen Handschriften des zehnten bis vierzehnten Jahrhunderts, Wiesbaden.

Kunitzsch, P., 1983, Glossar der arabischen Fachausdriicke in der mittelalterlichen europäischen Astrolabliteratur, Göttingen.

Kunitzsch, P., 2005, Stars and Numbers. Astronomy and Mathematics in the Medieval Arab and Western Works, Aldershot.

Lattin, H. P., 1932, „Lupitus Barchinonensis“, Speculum 7/1, s. 58-64.

Lindberg, D. C., 1978, „The Transmission of Greek and Arabic Learning to the West," in: Lindberg, D. C. (ed.), Science in the Middle Ages, Chicago, s. 52-90.

Millàs Villacrosa, J. M., 1931, Assaig d'història de les idees físiques $i$ matemàtiques, Barcelona.

Neugebauer, O., 1949, „The Early History of the Astrolabe. Studies in Ancient Astronomy IX,“ Isis 40/3, s. 240-256.

Poulle, E., 1995, „La littérature astrolabique latine jusqu'au XIII ${ }^{\mathrm{e}}$ siècle“, Physis 32, s. 227-237.

Pseudo-Beda, PL 90, Libellus de astrolabio, Migne, J.-P. (ed.), c. 955-960.

Samsó, J., 1995, „Roma et Francia (= Ifranja) in M. Destombes' Carolingian Astrolábe," Physis 32, s. 239-252.

Stevens, W. M.; Beaujouan, G.; Turner, A. J. (eds.), 1995, The Oldest Latin astrolabe, Physis 32/2-3.

van de Vyver, A., 1931, „Les Premières Traductions Latines $\left(\mathrm{X}^{\mathrm{e}}-\mathrm{XI}^{\mathrm{e}}\right.$ siècles) de traités arabes sur d'astrolabe," in: Premier congrès international de géographie historique, t. 2: Mémoires. Bruxelles, s. 266-290. 
Zuccato, M., 2005, „Gerbert of Aurillac“, in: Glick, T. G.; Livesey, S. J.; Wales, F. (eds.), Medieval science, technology, and medicine, New York - London, s. 192-194. 